We thank the following participants for including and treating patients in this study: R E Bernardus (Ziekenhuis Gooi Noord, Blaricum); H E Bobeck (Rode Kruis Ziekenhuis, Beverwijk); D D M Braat, W N P Willemsen (Universitair Medisch Centrum, Sint Radboud, Nijmegen); J W Briët (Deventer Ziekenhuis, Deventer); J Dawson, I van der Laar (Sint Lucas Ziekenhuis, Amsterdam); H J H M van Dessel, T J G Griffioen (Twee Steden Ziekenhuis, Tilburg); J P R Doornbos (Zaans Medisch Centrum, De Heel, Zaandam); J J Duvekot, H Versendaal (Medisch Centrum Rijnmond Zuid, Rotterdam); M H Emanuel (Spaarne Ziekenhuis, Haarlem); P A Flierman, H Verhoeve (Onze Lieve Vrouwe Gasthuis, Amsterdam); D A Gietelink, A M Bongers (Amphia Ziekenhuis, Breda); M H A van Hooff (Sint Franciscus Gasthuis, Rotterdam); P W H Houben (Gemini Ziekenhuis, Den Helder); Y M van Kasteren, R Weselius (Medisch Centrum Alkmaar, Alkmaar); C B Lambalk, J J M L Dekker (Vrije Universiteit

Medisch Centrum, Amsterdam); S van der Meer, C van Bolhuis (Medisch Centrum Haaglanden, Den Haag); A W J Omtzigt, P van Berlo (Flevoziekenhuis, Almere); C N M Renckens (Westfries Gasthuis, Hoorn); E Scheenjes (Ziekenhuis Gelderse Vallei, Ede); M A H M Wiegerinck, P Maas-van Son, B W Mol (Maxima Medisch Centrum, Veldhoven). We thank Nathalie Cugnardey, Merck Santé, France, and Louis L M van de Ven, Merck, Netherlands.

Contributors: See bmj.com.

Funding: Merck Santé France provided the metformin and placebo. No other funding was received.

Competing interests: None declared.

Ethical approval: The study was approved by the institutional review boards of all hospitals.
1 Nestler JE, Barlascini CO, Matt DW, Steingold KA, Plymate SR, Clore JN, et al. Suppression of serum insulin by diazoxide reduces serum testosterone levels in obese women with polycystic ovary syndrome. J Clin Endocrinol Metab 1989;68:1027-32.

2 Velazquez EM, Mendoza S, Hamer T, Sosa F, Glueck CJ. Metformin therapy in polycystic ovary syndrome reduces hyperinsulinemia, insulin resistance, hyperandrogenemia, and systolic blood pressure, while facilitating

3 Nestler JE, Jakubowicz DJ. Decreases in ovarian cytochrome P450c17 alpha activity and serum free testosterone after reduction of insulin secretion in polycystic ovary syndrome. N Engl J Med 1996;335:617-23.

4 Nestler JE, Jakubowicz DJ, Evans WS, Pasquali R. Effects of metformin on spontaneous and clomiphene-induced ovulation in the polycystic ovary syndrome. N Engl J Med 1998;338:1876-80.

5 El-Biely MM, Habba M. The use of metformin to augment the induction of ovulation in obese infertile patients with polycystic ovary syndrome. Middle East Fertility Society Journal 2001;6:43-9.

6 Glueck CJ, Phillips H, Cameron D, Sieve-Smith L, Wang P. Continuing metformin throughout pregnancy in women with polycystic ovary syndrome appears to safely reduce first-trimester spontaneous abortion: a pilot study. Fertil Steril 2001;75:46-52.

7 Jakubowicz DJ, Iuorno MJ, Jakubowicz S, Roberts KA, Nestler JE. Effects of metformin on early pregnancy loss in the polycystic ovary syndrome. Clin Endocrinol Metab 2002;87:524-9.

8 Heard MJ, Pierce A, Carson SA, Buster JE. Pregnancies following use of metformin for ovulation induction in patients with polycystic ovary syndrome. Fertil Steril 2002;77:669-73

9 Lord JM, Flight IH, Norman RJ. Insulin-sensitising drugs (metformin, troglitazone, rosiglitazone, pioglitazone, D-chiro-inositol) for polycystic ovary syndrome. Cochrane Database Syst Rev 2003;(3):CD003053.

(Accepted 28 March 2006)

doi 10.1136/bmj.38867.631551.55

\section{How times have changed}

From the moment that we decided to pursue a career in urological surgery, we met nothing but encouragement and support from our predominantly male peers and consultants. One wonders whether the same enthusiasm would have been offered to us 30 years ago.

Every urological trainee is advised to read the "bible" of endoscopic urological surgery, Transurethral resection by Professor John Blandy, which is now in its fifth edition. We came across the first edition, published in 1971, and, as eager trainees, quickly assimilated its many valuable lessons. However, it was with disbelief that we read Blandy's recommendations on the "care of the resectoscope," the most beloved instrument of us plumbers. ${ }^{1}$

"Ideally the surgeon should look after these instruments himself. The next best thing is to entrust them to a theatre technician with a natural propensity for gadgetstalent rare enough in men, and almost unheard of in women. Since theatre personnel are often female it is often best for the surgeon to assemble the instrument himself, and take it apart at the end of the operation, since these are the moments of greatest danger... A telescope snatched up roughly by a pretty blonde with a Cheatle's forceps or pressed firmly into its metal box for sterilisation, maybe ruined beyond repair."

Interestingly, this paragraph is nowhere to be found in the most recent edition of the book, ${ }^{2}$ and a review of all five editions suggests that political correctness reached urology in $1978 .^{3}$

Mahreen Hussain (mahreenhussain@hotmail.com), Charlotte L Foley specialist registrars in urology, North Thames Deanery, Chase Farm and Barnet NHS Trust
1 Blandy JP. Transurethral resection. London: Pitman Medical, 1971:23.

2 Blandy JP, Nottley R, Reynard JM. Transurethral resection. 5th ed. London: Taylor \& Francis, 2004

3 Blandy JP. Transurethral resection. 2nd ed. Tunbridge Wells: Pitman Medical, 1978.

Professor Blandy's response:

"Political correctness had nothing to do with it. I realised I was just plain wrong and that my theatre nurses were perfectly able to look after these instruments - so the sentence was withdrawn in later editions. Remember this was written at a time when transurethral resection was regarded as very dodgy: it was bound to make the patient incontinent even if he escaped getting a hole in his rectum; it always had to be done all over again and instruments (before the days of Harold Hopkins) were fickle and frail. I don't suppose anyone uses Cheatle's forceps for lifting things out of a sterilising boiler any more, but they certainly could wreak havoc with a resectoscope telescope, whether wielded by a blonde or not."

We welcome articles up to 600 words on topics such as A memorable patient, A paper that changed my practice, $M y$ most unfortunate mistake, or any other piece conveying instruction, pathos, or humour. Please submit the article on http://submit.bmj.com Permission is needed from the patient or a relative if an identifiable patient is referred to. We also welcome contributions for "Endpieces," consisting of quotations of up to 80 words (but most are considerably shorter) from any source, ancient or modern, which have appealed to the reader. 